\title{
Towards a full-fledged digital archives Experiments at the Japan Center for Asian Historical Records
}

Shohei MUTA

\begin{abstract}
The Japan Center for Asian Historical Records of the National Archives of Japan (JACAR) was established in November 2001 for the purpose of providing through the Internet the index and the digital image information of historical records about modern Japan-Asia relations held and made available to the public by Japanese national institutions such as the National Archives of Japan, the Diplomatic Records Office of the Ministry of Foreign Affairs, and the National Institute for Defense Studies of the National Defense Agency. The center is a full-fledged digitalized archives providing about 2 million images and 100,000 catalogues as of March 2002 solely relying on Internet access. The function of the center is to provide users with digitalized multi-page documents in a form that is faithful to the original, easily accessible, and searchable. In order to fulfill its objectives, the center introduced very unique technology and system such as the DjVu document compression technology, a catalogue system relying on the General International Standard Archival Description (ISAD (G)), and a digital dictionary for synonymous and related words specialized for Japanese modern history. This paper introduces these unique features of the center.
\end{abstract}

\section{1.はじめに}

アジア歴史資料センターは、2001年1 1 月 30 日独立行政法人国立公文書館の組織 として開設された。アジア近隣諸国との相互理解促進のために、政府が所蔵する戦前の公 文書からアジア諸国との関係資料を画像データとしてホームページ上で公開するとともに、 目録データベースの整備などアジア歴史資料に関する統括的な情報サービスを目的として 1999 年 11 月 30 日設立が閣議決定された施設である。現在、約 10 万タイトル、20 0 万画像を提供する本格的なデジタルアーカイブである。本論では、センターの情報提供 システムの概要と特長を中心に紹介する。

\section{2. 設立の背景と課題}

アジア歴史資料センター設立は1994 年「歴史図書・資料の収集、研究者に対する支 援等」を行う事でアジア近隣諸国の人々との関係改善を目的とする村山総理談話に端を発 する。政治・外交的な要請、公文書館制度、社会の情報化の現状を踏まえて、まず国立公 文書館、外交史料館、防衛研究所図書館が所蔵する「アジア歴史資料」をインターネット 
で提供することが閣議決定、2 年間の準備の後、昨年 11 月 30 日に開設された。現在、 200 万画像、10万件を越える目録データを提供する本格的なデジタルアーカイブであ る。毎年ほぼ同程度データが追加されていく予定である。既にこれまで一部の専門家にし か存在が知られていなかった日米開戦経緯に関する米国側外公文畫を暗号解読した日本側 の資料が提供されるなど内外の歴史研究者から日本近代史研究のあり方そのものを根底か ら変える試みであるとして注目されている。(「特殊情報」で検索)

我が国の文畫館を取り巻く環境は厳しいものがある。文畫館そのものに対する社会的な 認知も低く、博物館や図書館に比較して財政的な基盤も軟弱である。また、「アーキビスト」 は博物館学芸員や図畫館司書のように制度として確立したものではない。センターのデー タベース構築に協力が不可欠な資料所蔵各館も慢性的な専門職買不足に悩まされている。 所蔵する資料の整理分類作業だけでも手一杯で新しいセンターに資料を提供するための作 業負担は困難であった。限られた人的資源を前提に、いかに短期間で大量の画像と目録デ 一夕を処理するかが最大の課題であった。

\section{3. 情報提供システムの基本コンセプト}

アジア歴史資料センターは、インターネットで情報提供を行う本格的な「バーチャルア 一カイブ」である。成功の鍵は利用者が必要とする資料を簡便に検索し早く久手すること が出来るかにかかっている。そこで、以下に紹介する情報提供システムの基本コンセプト を採用した。(注 1)

\section{統一整理分類体系}

センターが提供するのは電子画像化された公文書資料である。図書と異なり原則とし て1点しかないユニークなものである。また、所蔵機関特有の方法で整理分類されており 日本 10 進分類法のような公文書館共通の整理分類方法はない。そこで既存の分類体系を 横断的に整理分類するために提唱されたのが 7 階層からなる共通整理分類体系である。国 際公文書館会議（ICA）が提唱する「国際標準記録史料記述：一般原則」（ISAD (G)）とわ が国の公文書整理の基本単位である簿冊（主題別や時系列に整理され緅じられたもの）を 基本の共通単位として 7 階層からなる「目録デー夕階層構造モデル」を設定した。これに よって、文書資料整理の国際的な規則となっている「出所原則」（フォンド尊重）を壊す ことなく、異なる所蔵機関の目録データ横断検索が可能となった。

目録項目は、各所蔵機関で運用されている目録分類体系を整理し $\operatorname{ISAD}(G)$ が提唱する 2 6 要素から我が国の文書管理の害態に即して選ばれた 15 項目とインターネット対応型書 誌項目 Dublin Core が提唱する 15 項目の特性を生かして提案された。さらにシステム搭 載のための管理項目として 5 項目が設定された。ISAD（G）では全ての階層に渡って目録 データが作成されるがセンターでは実用性を検討の上、第6 階層（ファイル、簿冊）と第 7 階層（アイテム、件名）の 2 つのレベルに対して作成されている。その他の階層につい てはインターネット上で階層別の解説を入れ、ツリ一構造を階層に沿って検索する「階層 検索」を導入することで対応した。(注 2)

「アーキビスト」による要約が必要とされる「内容」のデータ作成にあたっては、各資 料の先頭から３００文字程度を原文のまま抽出することを原則とした。これは、図畫目録 
にキーワードを付与する代わりに目次データを入力するようなものである。専門家の手を 煩わすことなく内容検索対象となるデー夕を大量に増やす事が可能となった。これは文書 の先頭 300 文字に歴史資料を特定するための基本的な情報である何時、何処で、誰が、 何のために作成したかが記載されていることが多いとの調査結果から決定された方法であ る。専門家による作業とは質的に比較できないが大量の目録情報処理のアウトソーシング には不可欠の手段であった。

\section{同義語・関連語辞書}

さらにインターネットで一般的な自由後検索を可能とする為に原資料に含まれる歴史用 語と現在使用されている歴史用語との乘離を埋めるための同義語・関連語辞畵を作成した。 例えば、一般に認知されている「太平洋戦争」は公文畫では使用されていない。そこで閣 議決定で正式名称として採用されている「大東亜戦争」を同義語として展開して検索でき るようにした。そこで辞書の編纂にあたつては同義語と関連語について詳細な検討が行わ れ、出来るだけ解釈が入る作業を排除する方法論が検討された。まず入力されるキーワー ドと同様の基本語の抽出が必要である。基本語は歴史用語辞典等典拠が明確な出典を利用 して抽出された。さらに基本語の解説から同義語および関連語を収録した。最後に資料の 件名データを形態素解析し基本語に対応する同義語・関連語を大学院生レベルの専門家を 動員して収録した。辞書編纂作業は今後も継続されより内容の充実が図られる。

同義語・関連語の定義

\begin{tabular}{|c|c|}
\hline & 定義と事例 \\
\hline 同義語 & $\begin{array}{l}\text { 当該語を置き換えても意味（概念）が変わらないもので、普通名詞およ } \\
\text { び固有名詞（実際の同義語には、読み、英語訳等も含む） } \\
\text { (1)漢字表記の不統一（誤字が歴史的に使われた場合も含む） } \\
\text { ・柳条湖事件／柳条溝事件／柳條湖事件 } \\
\text { (2)歴史的に用いら林名称と現在使われている名称（旧称の使用） } \\
\text { ・シンガポール／昭南／新嘉坡 } \\
\text { (3)同じ事象を指し示す異称 } \\
\text { ・日露講和条約／ポーツマス条約 } \\
\text { (4)歴史用語と現代用語 } \\
\text { ・大東亜戦争／太平洋戦争 } \\
\text { (5)正式名称と通称等（個人名も含む） } \\
\text { ・下関講和条約／下関条約／日清講和条約 }\end{array}$ \\
\hline 関連語 & 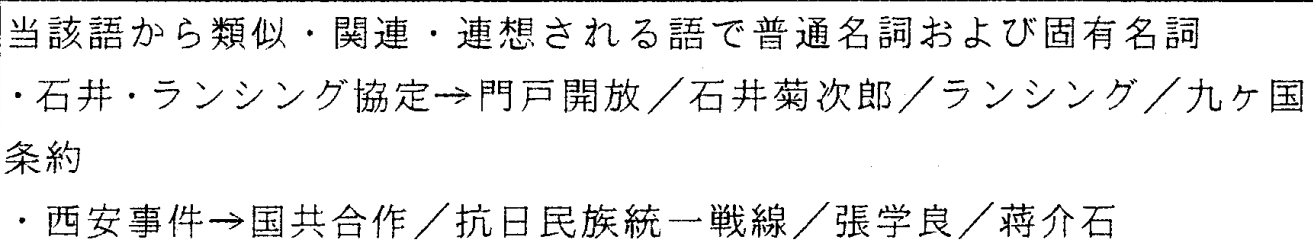 \\
\hline
\end{tabular}

検索がヒットするかは最終的には目録データと検索や検索語から展開される同義語・関 連語との整合性である。そのため双方のデー夕の抽出にあたっては共通の基準が不可欠と 
考えられた。ISAD $(G)$ では資料を特定するための用語や名称（アクセス・ポイント）として 人名、団体名、地名の3つを「オーソリティ・データ」として定義付けている。さらに ISAD (G) と対をなす「国際標準:団体、個人、家に関する記録史料オーソリティ・レコード」ISAAR (CPF) では記録作成者（組織、個人、家）に標準化された表記様式（典拠となる名称：オーソリ ティ・エントリー）を定めている。センターではこれらをもとに、歴史資料のオーソリテ イーエントリーといえるトピック、時間、場所、組織、人からなる「5つの軸」を目録デ 一夕抽出のための基準とした。(注 3 )

$「 5 つ の$ 軸」と考え方と目的

\begin{tabular}{|c|c|}
\hline 軸 & 意味 \\
\hline 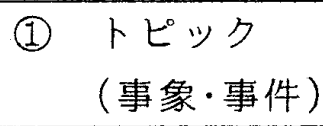 & $\begin{array}{l}\text { 歴史的な事件や事象等、一般的にキーワードとして検索に使われ } \\
\text { る。資料が何のために畫かれたかを定義することが可能。 }\end{array}$ \\
\hline (2) 時間 & $\begin{array}{l}\text { 資料固有の作成年月日や編纂された時期の情報で資料の時間的な } \\
\text { 位置を定義する。 }\end{array}$ \\
\hline (3) 場所 & 資料が作成された場所や資料が関係した場所を特定する。 \\
\hline (4) 組織 & 作成した組織を特定し組織の指示命令系統などを明らかにする。 \\
\hline (5) 人 & $\begin{array}{l}\text { 各資料に関係した人に関する情報で報告者や報告書の作成者、報 } \\
\text { 告の対象となる事件等の関係者などを特定する。 }\end{array}$ \\
\hline
\end{tabular}

\section{高度画像圧縮技術およびマイクロ・デジタル化の標準仕様}

センターの主たる機能は文字コンテンツをいかに早く提供するかである。紙質や色の復 元など高画質が必要とされる貴重書画等を扱うバーチャルミュージアムとは異なる。そこ で文字情報の電子化にあたってはマイクロフィルムや画像電子化技術の成熟度を勘案して 文字が研究に支障ないレベルで判読でき情報提供量を最大化できる妥協点としてもノクロ 2 值、400 dpi、TIFFファイルを標準仕様として採用した。さらに現在最高レべルの画 像圧縮性能（モノクロ 2 值ではJPEGの 20 倍程）DjVuを採用した。DjVuは文字データを 高度に圧縮するために開発された次世代型画像フォーマットで文字情報が判読可能な状態 で高度圧縮が可能である。資料の拡縮（ズーム）やページ送り、サムネイルによる指定ペ ージへの移動、判読が困難な部分だけの拡大機能など資料閲覧のための高度な機能を備え ている。(注 4)

\section{4. センター概要（検索の実際）}

「アジア歴史資料データベース」には2002 年 3 月現在、国立公文書館、外務省外交史料館、 防衛庁防衛研究所所蔵のアジア歴史資料、約 200 万画像、10 万件を超える目録がデータベ ース化されている。このデータベースはインターネットを通じて、いつでも、たれれでも無 料で利用できる。データの軽量化のために無償提供されるビューアー（ブラグイン）以外 に特定のOSに依存しないオーブンデータベースである。 


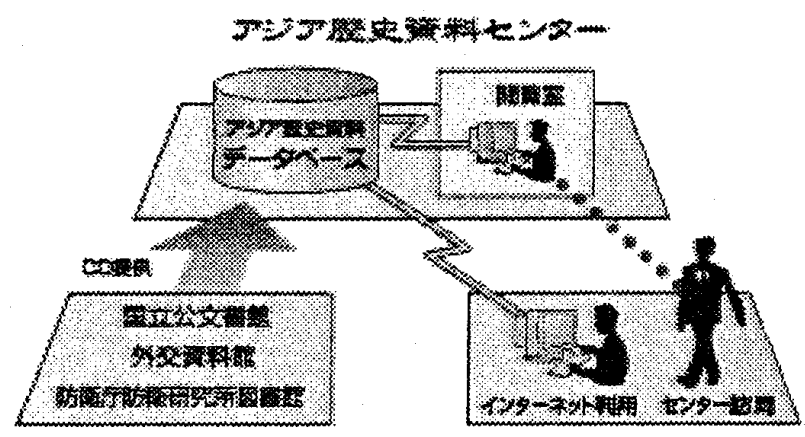

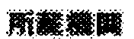

数稳

さらにセンターの特長は、利用者の利便性に配慮した 「階凩検索」各所蔵機関毎に分類をたどりながら目的とする資料群を検索するシステム である。所蔵機関 $\rightarrow$ 出所 $\rightarrow$ あリーズーサブシリーズと階層を下りながら絞り込んでいく方 法である。選択した階層毎に簡単な解説が表示される。第 6 階層のファイル（簿冊）では 対象となる簿冊名がリストとして表示され、第 7 階層のアイテム（件名）では選択された 簿冊に含まれる資料の一覧が表示される。この検索は各所蔵機関の資料体系を熟知してい る研究者や所蔵機関別に漏れなく資料を閲覧することを想定して採用された。

階層検索画面

\section{展届梌索}

\section{鲜䛊 :}

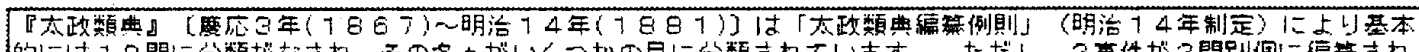

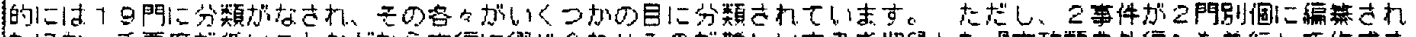

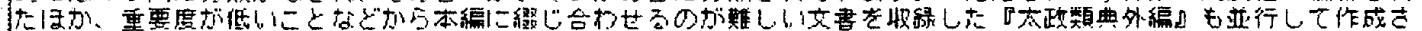

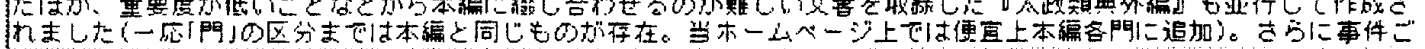

\begin{tabular}{|c|c|c|}
\hline 理電: & 国立公安吾馆 & 3 \\
\hline 出唔 : & 内閣 & 2 \\
\hline シリース: & 太政類典 & 3 \\
\hline サテシシリーズ： & $\sqrt{\uplus ア ゙ シ リ ー ス ゙ を ~}$ & டださい! \\
\hline
\end{tabular}

「キーワード検索」自由語検索に同義語・関連語辞書の展開機能、年代域による絞込み 機能を付与している一般の利用者を想定した検索システムである。検索は第 $6 、 7$ 階層の 目録データに収録された情報について行われる。

「キーワード詳細検索」検索対象機関の指定、検索項目（表題、作成者、内容、組織歴 . 履歴）毎のキーワード設定、入力したキーワードの同義語や関連語の展開や削除、年月日 まで特定可能な年代域の指定など検索条件をより絞り込んだ検索が可能である。異なる所 蔵機関の資料を統一された項目で検索できるアジア歴史資料センターの情報システムの特 性を生かした検索方法である。 
「キーワード詳細検索」での同義語・関連語辞書の展開

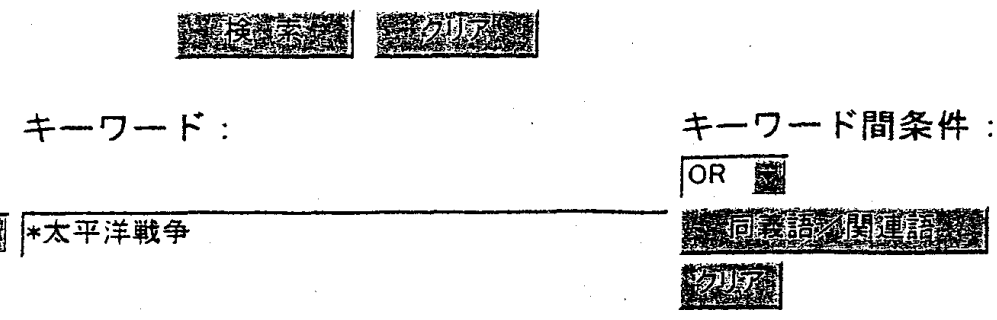

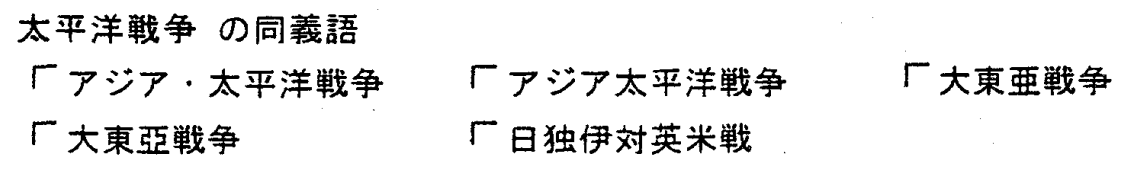

太平洋戦争 の関連語

「1941年12月8日 「A. B. C. D対日包囲陣「支那事変

厂昭和16年12月8日 「昭和十六年十二月八日「対英米亘戦

厂対米英戦

$\Gamma$ 対米戦争

「大東亚会議

$O R$

\begin{tabular}{|c|c|}
\hline すべて 盗 & 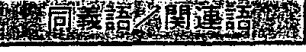 \\
\hline
\end{tabular}

AND 盗

OR 鋅

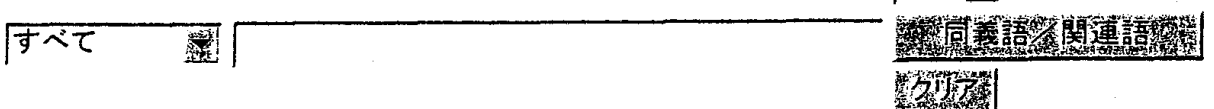

\section{5. 今後の展開と可能性}

時間的な制約や文書館を取り巻く環境、情報基盤の現状を考えると、センタ一情報提供 システムに多くの改善すべき点があることは避けられない。そのためモニター制度などを 活用して利用者の生の声を聞きサービスの改善を進めていく予定である。また、広く海外 からの利用を促進するため多言語化への対応を検討する。特に英語での情報提供はインタ 一ネットで情報提供を行う以上不可欠と考えられる。そこで件名の英語化を行い、英語で の検索を可能とするためのシステム開発を行っている。センターの情報提供システムは， 大量の文字コンテンッのインターネットでの提供を主目的とするものである。文字がコン テンツの中心となる大量の行政情報公開等に新しいモデルを提供するものである。

注 1. 詳練に関しては「アジア歴史資料センターについて」『アーカイブズ』第 8 号、国 立公文書館、平成 14 年 3 月を参照

注 2。目録の国際記録標準の詳細に関しては『記録史料記述の国際標準』(北海道大学図 書刊行会、ア一カイブズ・インフォメーション研究会編訳、2000年）を参照

注 3.ISAAR(CPF)に関しては『記録史料記述の国際標準』p.132-136 を参照

注 4.Djvuの技術的な詳練はWWW.lizardtech.com または wwi.keiyou.co.jD 